\title{
Legal Certainty Perspective on Ulayat Land Ownership in Bali
}

\author{
I Made Suwitra, I Nyoman Alit Puspadma \\ Faculty of Law \\ Universitas Warmadewa \\ Denpasar, Indonesia \\ madesuwitra@warmadewa.ac.id
}

\begin{abstract}
This paper examines the model of certainty and legal protection on the ownership of Ulayat Land of Desa Pakaraman (Traditional Village). Normative legal research method was used to describe the uncertainty and duplication of norm between Agrarian Law, Decree of Minister of Agrarian and Awig-awig (Customary Law), as a local law of Balinese society. The data collected includes the written form of rules of agrarian law and Awig-awig, and library study utilizing documentation and recording techniques. The result shows that the model of Ulayat Land ownership is executed preventively and repressively based on customary law and government law. Meanwhile, legal certainty over the ownership of Ulayat Land can be realized in the form of proprietary proof. The simple consideration is that by the appointing Pakraman Village as the subject of communal ownership of land, there will be a rejection of the existence of the Ulayat Rights of individuals and the public.
\end{abstract}

Keywords-Pakraman Village, Ulayat Land, ownership rights, legal certainty

\section{INTRODUCTION}

Massive transition of Ulayat land rights is into individual land in some villages in another area in Bali, such as those in Pakataman of Karangasem [1]. The transition process may proceed in accordance with the procedures under State law. The implication is the strengthening of individual rights over land to communal rights. Prajuru Adat (Traditional Village Head) and the community today are unaware of the implications of the weakening of Pakraman Village's relationship with the converted land.

The massive transition of Ulayat land has implications for soil conflicts [1]. In Karangasem, one of regencies in Bali, there is land belonging to communal property which is believed to be the land given by the king. The land is called Pauman. Pauman's land control is still communal and still provides individual economic benefits, although the value is not so great. All actions of the Pauman community are the result of the principle of obligatory attachment called "ayahan" from human soil. The management model was initially performed among Pauman members with a profit-sharing system, and changed according to the present conditions. While the policy setting model is still local, it is still only shaded by Awig-awig, the local law, of Pauman. The existence of Pauman is still sustainable, but in some villages it no longer exists [2].
Another study has been conducted by I Putu Gede Gianta. Gianta found that the status of AYDS land as one of Ulayat, after being certified for individual ownership in Traditional Village, implies that individual rights become stronger while Pakraman Village's rights become weak and even disappear. Then to prevent the transition, in the local law of Pakraman Village, the Ulayat transfer of land is strictly prohibited [3]. So controlling rights can be transferred through sales with mandatory attachments called "ayahan" to Banjar, Pakraman Village and Pura Kahyangan Tiga (The Tample).

Through the enactment of the Decree of ATR 276/2017 in appointing Pakraman Village as the legal subject of communal land ownership, it can be interpreted that Pakraman Village in Bali can register its Ulayat land as a "common property" called "druwe Desa" as arranged in Awig- Awig to obtain a Property Certificate Community (SHM) as a new model, so that the legal issue concerning tenure rights over Ulayat land in Pakraman Village must be done with proof of certificate of communal ownership right.

\section{METHOD}

The study in this paper uses normative legal research methods since this method is the basis for the application of legal norms of the Decree of the Minister of Agrarian Affairs, Agrarian Basic Law and other regulations in agriculture and Awig-awig. The legal approach used is the legislation approach to examine the laws and regulations and the hierarchy of legislation and conceptual approaches, developed in practice and law science [4]. The data used are the Constitution of the Republic of Indonesia Year 1945 [5]; Law No.5/1960 on Basic Agrarian Law (UUPA); Regulation of the Minister of Agrarian Affairs/Head of BPN 5/1999 on Guidelines for the Settlement of Communal Community Rights Problems (Permenag 5/1999); Ministry of Home Affairs Decree no. SK. 556 of 1986 concerning the Appointment of Pura as a Religious Entity with Own Right (Kepmendagri 556/1986), Regulation of the Minister of Agriculture and Spatial/Head of National Land Agency of the Republic of Indonesia No. 10 Period 2016 on the Procedures for the Establishment of Communal Rights in Land and Communities of Indigenous Peoples in Specific Areas (Permen ATR 10/2016 Kepmen ATR 276/2017, Awigawig, and various literatures, scientific documentation and publications, and dictionaries [6] The data were collected by 
documentation and recording techniques through file system [2]. The data were analyzed by hermeneutical analysis technique, which initially refers to the interpretation of religious texts, to understand social life [7].

\section{RESULT AND DISCUSSION}

\section{A. Model of Ulayat Land Rights Protection in Bali}

The relationship between indigenous peoples and tribal peoples and occupied land is a religious magic that is so close. As a result, customary society has the right to control the land, to use the land, to collect the proceeds from the plants that live on land, and to hunt down the animals that live there. The rights of indigenous peoples and tribal peoples to this land by van Vollenhoven are called "beschikkingsrecht" which came to be known as Ulayat rights or Pertuanan or hak Prabumian [8]. Ulayat right is an authority which, according to customary law, belongs to a community of customary law over a particular area which is the environment of its citizens to benefit from natural resources, including land within the territory for the survival arising from the family is inherited without disturbing the customary and tribal peoples (Article 1 point 1 of Permenag 5/1999). While Tanah Ulayat is defined as a plot of land with customary rights from certain customary law communities (Article 1 point 2). In the Ulayat Right there are two elements, namely the element of ownership (not the right of ownership in the sense of juridical technique) and the element of authority to organize, plan, lead which in modern law covers the field of public law which can only be done by customary society as alliances which have "Autonomy "in the perspective of communal religion.

Furthermore, to date the strength of the relationship between Desa Pakaraman and its Ulayat land is regulated in a local legal rule called Awig-awig. The laws governing Ulayat land rights in the Awig-awig are known as "Druwe Desa" by the community in every Pakraman village. Ulayat land is listed as village property as stipulated in Article 25 of the Awig-awig on Druwen Village (belonging to the village community), including: Kahyangan Desa or The Tample of Pura Dalem Kayu Pitih: 1640 m2, Candi Batur: 1215 m2, Pura Aji Ketekan: 2040 m2, Candi Melanting: 385 m2, Tangan Dalem Anggar: 1100 m2, Pura Dalem Kelod: 800 m2, Pasar Traditional Village, Tanah Tegalan, Village Yard (PKD) is an area where traditional village members to build houses, Setra (Hindu Village Tribe), Pura Pelaba (temple owner): $55676 \mathrm{~m} 2$, Village Credit Institution (LPD), Village Hall, and others according to the recording (Ilikita). With respect to the land of the PKD and AYDS, the right of individual ownership as members of the alliance becomes more dominant, especially in the utilization and use of it, although it remains in the Ulayat right of the village [2]. Commitment of traditional customary ruler and community fellowship is continuously tested in maintaining the existence of Ulayat land to be utilized and used according to religious communal principles and the philosophy of Tri Hita Karana.

The right on land or land title is a legal relationship that gives the authority to do something about the land. The ownership on this land can be used in a physical and juridical sense. The notion of ownership and domination here can be civil and public dimension, but disaggregation is unambiguously unknown in customary law. The mastery in the civil dimension is the control that gives the "authority to use" the land concerned, while the mastery in the public dimension, gives "authority to the holder (Pakraman Village) to administer and regulate" the land (territory) it controls [9]. Once the mastery is factual, the law is required to make decisions about it. If the law begins to come in then he must decide whether a person will get protection or not. If he decides to grant recognition and protection of a person's dominion over an item, he will protect the person from the interference of others. Thus mastery in addition has a physical meaning, also juridical [10].

Both aspects of this mastery basically want the recognition and protection of the interference of others. Indeed, in this juridical sense of authority, its acknowledgment and protection will become clearer and clearer because it is based on rights, which is protected by law and generally authorizes the right holder to physically control the land in custody. In this control is also contained the nature of ownership in it, namely the existence of a series of rights means a compelling claim against a usefulness or benefit something, whether it is the right to participate in enjoying a common source or an individual right over certain property. This condition is also relevant to the understanding of natural law, as Cicero stated, that what is produced by nature to be used together must be maintained and respected. So naturally there is only a common property, while private property is only artificial [11]. The main norm of justice dictates that human beings should not harm one another and that people use property appropriately, in order to preserve the cosmopolitan unity, to maintain the universal brotherly bond between humanity. The goal is to harmonious and harmonious lives between people not to be disturbed or destroyed in connection with the use of the common property. The conceptual or philosophy underlying customary law of land is the conceptual communalistic religion [12]. Therefore, customary law views the life of the individual as a life that is primarily intended to serve the society [13]. It is relevant to Ulayat land arrangements in Awig-awig in Bali.

The model of protection of Ulayat land as the ownership of Pakraman Village in the concept of "justice as" fairness "[14], on the one hand justice refers to the value that directs each party to give protection to the rights guaranteed by law right). While on the other hand, this protection should ultimately provide benefits to every individual (element of benefit). Tenure of Ulayat land in Bali is directed to provide benefits to communal residents to utilize and use the land of PKD and AYDS, but also at the same time provide benefits to the village of Pakraman in the form of bond obligations called "ayahan" to the citizens of the fellowship to serve Pakraman Village.

Based on the philosophy and moral teachings on the formation of the state, the state has an obligation not to violate the rights of tenure and ownership of Ulayat lands of indigenous and tribal society (respects), and is also obliged to protect in the sense of preventing and taking action against its violation (protect). Hence, the state has an obligation to recognize the right of every citizen in the sense of respecting as well as protecting and fulfilling them. One of them is the right of ownership and ownership of communal land which is still felt vague, as if the tenure and ownership of communal land by 
Pakraman Village in Bali do not obtain full access from UUPA and other legislation [2]. If there is a limited recognition of the State on the Ulayat Land Rights and Ulayat Land of Customary Law Community, it has been arranged in a limitative manner in Article 18B Paragraph (2) of the Constitution of the Republic of Indonesia (UUD NRI) Amendment 4, Article 3, Article 2 Paragraph (4) of Basic agrarian Law (UUPA), Regulation of the Minister of Religious Affairs (Permenag) 5/1999, Amendment of Decree of the Minister of State (Kepmendagri) 556/1986. However, only Laba Pura land can be registered to obtain a certificate of ownership after being issued by Kepmendari 556/1986. Thus, in other provisions there is no technical guidance when the Ulayat Land is registered as the village assets through a certificate of Right of Management (HPL) as well as the Swatantra area (Autonomy of District (Article 2 paragraph 4 UUPA)), or obtaining proof of registration in the land basis as Ulayat Land of the village according to Permenag 5/1999.

In the concept of protection there are two main elements, namely there is a guarantee on the implementation of a series of rights and avoid discrimination, there is a guarantee of security from the interference of others and repressive legal protection [15]. On preventive legal protection, society are given an opportunity to file their objections or opinions before a government decision gets a definitive form. So if there is a claim or proof of claim on Ulayat Land in a preventive way. This can attained through the Awig-awig or through a process in the Awig-awig based on judicial institution which has been strengthened by the recognition of the state law (UUD NRI 1945; UUPA; Kepmenag 5/1999; Kepmendagri 556/1986). Model of protection of Land of Laba Pura as Ulayat Right or as Communal Right is done through conversion according to Kepmendagri 556/1986). So since 1986 the lands of Laba Pura can be converted on behalf of Pura, since previously registration of rights to Land of Laba Pura is done on behalf of one Prajuru Pura (Pura Manager), or on behalf of Pinandita (Jero Mangku that is religious officer) it's Pura.

\section{B. Legal Certainty on Ownership Rights of Private Land According to Decree of Religion Minister (Kepmenag) $276 / 2017$}

According to Radbruch certainty in the law is achieved will be achieved if the law set as well; in the Act there are no conflicting provisions, the law is made based on rechtswerkelijheid and in the Act there are no interpretable legal terms in different ways [16]. It is relevant to Kelsen's "Pure Theory of Law" who developed the Story Theory (Stuffen theorie) which views the law as a system consisting of pyramid-shaped norms. Lower norms gain strength from higher norms [17]. This theory is then developed by Hans Nawiasky and so on followed by observing the hierarchy of laws and regulations as set forth in Article 7 of Law No. 12/2011 on the Establishment of Legislation Regulations, namely with the composition of the Constitution to District Regulation.

The review of legal certainty over the appointment of Pakraman Village as the subject of communal ownership of the land is executed by observing the hierarchy of relevant legislation, namely: Basic Agrarian Law (UUPA) in Article 2 Paragraph (4) which in principle states that the right to control the state in its implementation can be empowered to the regions and customary law communities, so that the Right of Management (HPL) granted to the Swatanra Area (Region autonomy) by issuing the HPL certificate as Land of Provincial Government, Regency/City Asset that can also be granted to Pakraman Village with HPL certificate to Ulayat land as an asset of Pakraman Village . On the other hand, the UUPA through Article II on the Conversion Provision provides an opportunity for an increase in land tenure rights that were initially adopted according to customary law such as land for PKD and AYDS to become property rights under the UUPA. Thus, UUPA in addition to providing an opportunity to strengthen the existence of Ulayat Land also provides more opportunities to weaken and even eliminate the existence of Ulayat land, especially on Ulayat land whose mastery is performed individually. In reality most of Krama (society members) of Pakraman Village take advantage of opportunities to convert their Ulayat land as those happened in Ngis Village, many other areas in Bali [2]. Kepmendagri 556/1986 publication shows the State's commitment to strengthen the Ulayat Land existence, especially Laba Pura in the form of rice fields to be certified on behalf of Pura. However, until now Tegak Pura (the land where it stands of the temple) is not yet certified, which can be due to several things, such as: the perception of security from the claims of others, there is a belief in the power of the Law of Karma for those who dare to grab the land of Tegak Pura. On the other hand, by the issuance of Permenag 5/1999, Ulayat Land which is still controlled by Ulayat Right can be strengthened by placing Ulayat Land in the basic map of land registration which is marked with Cartography sign depicting the boundaries and record it in the list of land which is subsequently regulated in the Regional Regulation of City/Regency.

Registration of Ulayat Land in the PTSL program can adversely affect the existence of Ulayat Land especially the land of PKD and AYDS which will become the right of individual ownership, and the loss of customary law ties in the form of obligations in the form of "swings", because through Conversion there will be a transfer of tenure according customary law becomes the right of ownership according to UUPA, so that by referring Ballon Theory Ter Haar or MulurMungkretnya Iman Sudiyat [18], the Ulayat Rights become weak and even disappear, then emerge the right of individual ownership strongly. So the registration of land of Ulayat Pakraman Village through conversion facilitated by PTSL jo Kepmen ATR 276/2017 is a "sudden storm" volume II, because for Ulayat land which is controlled by individual (PKD and AYDS) is converted to Owner Right, while Ulayat Land is tenure with Ulayat Right will become the Land of Communal Ownership. With the publication of Kepmen ATR 276/2017 hierarchically there has been duplication with existing laws and regulations, such as UUPA, Permenag 5/1999. Even when associated with the PTSL program there is a confusion in the appointment of the subject of its rights especially in the registration of land PKD and AYDS. Meanwhile, against the Ulayat Land which the mastery is still carried out by the Village in some villages is denied to be registered. This condition reflects the variety of views and practices of the Ulayat land registration model. It is in this context that turmoil arises that concerns the "sudden storm" of 
volume II, since Bali is the only one that can serve as an example of a still united legal alliance with its customary law including the Ulayat Right with its Ulayat Land. Therefore there is an incoherence between Kepmen ATR 276/2017 with the above rules and violates the hierarchy and legislative principle, namely "Lex Superiore derogat legi inferiore", so there is no legal certainty in the registration of Ulayat land rights of Pakraman Village let alone registered became a communal property right that could weaken Ulayat Land into Communal Land such as Pauman land in Karangasem, or some Communal land of indigenous peoples in Sulawesi, Lampung, Kalimantan. The most worrying is individualization through conversions facilitated by private universities to private Ulayat land such as PKD and AYDS which implicate the extinction of all private and privately owned land (not villagers). As a result, there is no obligation bond between the land owned by the villagers to maintain the existence of Pakraman Village as a bond in the Ulayat Land Right.

\section{CONCLUSIONS}

Hierarchically, legislation of the State in the field of land such as Basic Agrarian law (UUPA), Permenag 5/1999, and Kepmendagri 556/1986, is intended to protect the existence of Ulayat Land of indigenous and tribal society. However, not all Ulayat lands have been securely protected in accordance with the model established by the law of the country, except for the land of Laba Pura which can be given proof of ownership on behalf of the temple. While for other Ulayat land arrangement in the form of Local Regulation or technical guidance is still needed when Pakraman Village will be given HPL as asset land of Pakraman Village like HPL as land asset of Local Government. Therefore, the protection of Ulayat land is executed through Awig-awig Pakraman Village.

The publication of ATR 10/2016 jo Kepmen ATR $276 / 2017$ is also intended to protect the existence of Ulayat Land of Pakraman Village, but on the contrary that the appointment of Pakraman Village as a subject that can carry out communal ownership of land, which normatively can be interpreted that there can be a weakening of Ulayat Land status into a Communal Land, even with PTSL as Ulayat land which is individually will be converted into individual property rights according to UUPA which resulted in the extinction of Ulayat land intended.

Observed from the hierarchy of legislation, the existence of Kepmen ATR 276/2017 is inconsistent with the above regulations, so it cannot be stated to guarantee legal certainty. Therefore, a concept and analytic approach is needed to understand the protection and legal certainty of the existence of Kepmen ATR 276/2017 on the preservation of Ulayat land of Pakraman Village so that Ulayat lands that are individually tenure by the gods can still be maintained in the implementation of their obligations in maintaining the preservation of Pakraman Village on an ongoing basis. It is hoped that the program of PTSL targeting Ulayat Land is not based on the target to meet the quota of certificate in each regency/city, but based on the effort to protect and recognize the existence of Ulayat Land so that Pakraman Village has a bargaining position when dealing with outsiders in organizing and leading designation of its Ulayat Land.

\section{ACKNOWLEDGMENT}

My Rector Warmadewa University, Dean Faculty of Law, International Conference Committee, and Indexing Institution.

\section{REFERENCES}

[1] Suwitra, I. M. M. W., I Nyoman Sujana, "The Impact of Registration of Land Rights in Bali", Competitive Grant Research Report, Warmadewa University, Denpasar. 2012.

[2] Suwitra, I. M., "The task of Customary Prajuru in regulating the customary land, especially the land of teljakakan in the concept toward Bali is steady", Kertha Wicaksana. Faculty of Law, University of Warmadewa, Denpasar, (11) 1. 2005.

[3] Gianta, I. P. G., "Pengertipikatan Tanah Ayahan Desa in Sibangkaja Abiansemal Badung Village", Thesis, Faculty of Law, University of Warmadewa, Denpasar. 2013.

[4] Marzuki, P. M., Research Law, Print I. Fajar Interpratama, Surabaya. 2005.

[5] UUD NRI Tahun 1945 (Constitution of the State of the Republic of Indonesia)

[6] S. Soekanto and S. Mamudji, Normative Law Research A Brief Review, First Printing, CV. Rajawali, Jakarta. 1985.

[7] E. Babbie, The Basics of Social Research, Wadsworth Publishing Company, USA. 1999.

[8] S. Wignjodipuro, Introduction and Principles of Customary Law, Issue III, Alumni, Bandung. 1979.

[9] Setiawan, K. O., "Customary Rights of Indigenous Villages of Tenganan Pegrinsingan Bali Post UUPA", Printed I. Dissertation, Postgraduate Program Faculty of Law University of Indonesia. Jakarta. 2003.

[10] B. Harsono, Indonesian Agrarian Law History Formation of UUPA Content and Implementation, Volume I of National Land Law. Ninth Printing, Djambatan, Jakarta. 2003.

[11] Sonny, K. A., Law of Nature \& Private Property Theory, Kanisius, Yogjakarta. Suastawa Dharmayuda, M. 1987, Status and Function of Indigenous Land of Bali After the Enactment of UUPA, Print I, CV Kayu Mas, Denpasar. 2001.

[12] Sitorus, O., Capita Selekta Comparison of Land Law, Initial Printing. Partner of Land Policy Indone. Yogyakarta. 2004.

[13] Soepomo, R., Chapters on Customary Law, Third Printing, Pradnya Paramita, Jakarta. 1979,

[14] Rawls, J., A Theory of Justice, The Belknap Press of Harvard Universiy Press, Cambridge, Massachusetts. 1971.

[15] A. Sodiki, "Arrangement of ownership of land rights in Philipus M. Hadjon. 1987. Legal Protection for the People in Indonesia, a study of its Principles, its Treatment by Courts within the General Courts and the Establishment of State Administration Courts, First Print. PT. Bina Ilmu, Surabaya. 1994.

[16] Utrecht, E., Introduction in Indonesian Law, Sixth Matter, P.T. Publishing and Ichtia Bookstore, Jakarta. 1959.

[17] D. Darmidiharjo and Shidarta, Principles of Legal Philosophy, Second Edition, Revised Edition, PT. Gramedia Pustaka Utama, Jakarta. 1996.

[18] Iman S., Customary Law of Sketches of Principles, Liberty, Yogyakarta. 1981. 